\title{
An evaluation u-turn: From narrow organisational objectives to broad accountability.
}

As many scholars have observed in the recent past, debates about public relations measurement and evaluation (M\&E) have reached deadlock (Macnamara, 2014), stasis (Gregory \& Watson, 2008) or are like a car with its wheels spinning round in the mud where there is little forward movement (Gregory \& White, 2008). The lack of traction gives rise to many questions, but two are relevant for this paper. First, if there are the processes and tools needed to measure and evaluate programmes comprehensively, why do practitioners not evaluate or only use part of the toolkit? Second, why is it that the measurements and evaluations that are undertaken do not seem to be of significant importance to or meet the needs of senior management? These questions are important and have been outstanding for a number of years.

With regard to the first question, it was James Grunig who stated back in 1983 (Grunig, 1983), that despite knowing that not evaluating is a sin, practitioners keep on sinning. Since then, many studies have shown that evaluation in public relations is either not done, or predominantly focussed on the outputs, rather than the outcomes or impact of communication (Gregory, 2001, Macnamara, Lwin, Adi, \& Zerfass, 2015; Wright, Gaunt, Leggetter, Daniels, \& Zerfass, 2009; Watson \& Noble, 2014; Wright \& Hinson, 2012; Zerfass, Verčič, Verhoeven, Moreno, \& Tench, 2015).

In relation to the second question, as Murray and White (2005) found in their interviews with 14 CEOs and chairs of boards, the quest for definitive information on the performance of public relations appears to be a practitioner (or service provider) obsession. These interviews showed that senior leaders understand that public relations work (as is that of other management functions such as HR and legal), is not always amenable to precise measurement. Furthermore, they are too busy to be inundated with huge amounts of detail. However, they want information that is sufficient and reliable enough to help them avoid wasted effort and mistakes - in other words to help them in in future decision-making. This perspective was supported by Baskin et al (2010) who found that users of public relations services feel they have plenty of information about what has been done in the past. Macnamara (2015), in his interviews with senior management, found that they do not want to dwell on what has happened, but rather that they 'are more likely to pay for what they do not know and what can change the future' (p.380). In addition, research indicates that the language and focus employed in public relations evaluation is alien to senior managers, even if the process underlying $M \& E$ is not, and this adds to its lack of impact.

The two questions posed above are of course linked. If practitioners do not use M\&E processes and tools properly and, as Macnamara (2015) argues, exploit them as potential sources of intelligence 
that are critical to the sustainability of their organisations both short and longer term, then it is little wonder that M\&E does not have the influence with senior management that practitioners seek. It is also unsurprising that, in the absence of more useful information critical to future performance, questions arise from senior management in relation to return on investment (ROI) and practitioners struggle to answer such a question, certainly in financial terms commonly associated with ROI. Murray and White (2005) discovered that very senior leaders recognise public relations as an essential business cost, and, at its best, essential to business and organisational performance. But without clear demonstration of business and organisational value-added, senior managers focus on cost.

\section{Research Questions}

It is consideration of these reflections that has prompted this paper and focussed it around two research questions

RQ 1: is there a 'direction of travel' that can be discerned in the models outlining the process of measurement and evaluation?

RQ 2: Given that both practitioners and organisation leaders do not appear to be satisfied with what is currently being supplied, is there an alternative approach that might address their concerns? To explore these questions, this paper is structured in five parts. First, four of the more popular evaluation models are examined to establish the common approaches in the field. This first part will also consider other 'voices' that appear to have been side-lined or have recently emerged. This identifies counter voices to the mainstream in M\&E thinking.

The second part will provide a brief examination of a selection of the more recent academic and practitioner thinking in business and management in the area of strategy. Strategy is chosen on the basis that many of the evaluation models seek to demonstrate that public relations work has organisational impact and contributes value, inter alia, they must be in alignment with organisational strategy.

Third, implications that arise from analysis of public relations evaluation literature and current thinking in business practice and management literature are examined. 
Fourth, an extant model from the public relations literature (Gregory \& Willis, 2013) that has not been used in the evaluation context before, but that addresses identified implications will be adapted to provide the more radical turn required if $M \& E$ is to break free of its current impasse.

Fifth, this paper offers conclusions and recommendations for next steps.

\section{Methodology}

This is a conceptual paper informed by critical literature review and qualitative research undertaken over a number of years. Specifically, it is informed in three ways as follows.

First, critical analysis of the public relations M\&E academic literature and the literature published by professional associations such as the Chartered Institute of Public Relations (CIPR) in the UK and the International Association for Measurement and Evaluation of Communication (AMEC), and research organisations such as the Institute for Public Relations (IPR) in the USA. The researchers would not claim that their examination of the body of knowledge underpinning this paper was exhaustive, but it did embrace over 250 journal articles, book chapters, professional articles and reports spanning a 40 year period. It is not the purpose of this paper to provide a comprehensive M\&E literature review since that has been covered by authors such as Likely and Watson (2013), Macnamara (2018) and Watson and Noble (2014).

The management literature is also referred to on a selective basis, with the main strands of contemporary thinking on the strategy process being drawn on to inform this paper. Space constraints prohibit a more comprehensive review.

Second, the paper is informed by a review of 30 M\&E reports for major corporations, governments and government agencies, international public relations consultancies and providers of M\&E services, all produced since 2005, with the majority from 2010 onwards, so they can be regarded as contemporary. The reports were a convenience sample of reports made available to the researchers and consist of formal evaluations of substantial campaigns and programmes.

Finally, the paper is informed by the significant amount of non-participant and participant observations undertaken by the researchers. Both authors have for over 15 years and are currently involved in observation of and participation in a number of industry initiatives including: the development of the International Association for Measurement and Evaluation of Communication (AMEC) Barcelona 2.0 Principles (AMEC, 2015), AMECs Integrated Evaluation Framework (AMEC, 2017) and serving on AMECs academic advisory Board, one as Chair. One researcher also serves on 
the Task Force on Standardization of Communication Planning and Evaluation Models, a collaboration of academics and practitioners brought together by the Institute for Public Relations in the US (IPR), whose aim is to develop standardised approaches to M\&E including standardising the terminology used and well as the processes and practices. Both have been involved in public sector initiatives such as what is regarded as the internationally leading UK Government Communication Service Evaluation Framework and the attendant training package (GCS, 2016); involvement in the development and delivery of the Directorate-General for Communication (DG COM) of the European Commission (EU) M\&E standards, guidelines and training EC, 2014, 2015a, 2018). One author has also worked with the Department of Premier and Cabinet of the New South Wales government in Australia helping to design and implement an evaluation framework and methodology. Both researchers have been involved with large and small private sector organisations and NGOs in the UK, Europe, Scandinavia, Asia, Africa, Latin America and Australasia as advisers, consultants and trainers in evaluation. In addition, one researcher has been involved in the launch of the International Integrated Reporting Council initiative that seeks to establish integrated reporting and thinking within mainstream business practice in public, private and NGO sectors.

Collectively, these sources have provided a rich insight into the direction academic and practitioner thinking, into the endeavours and challenges facing and practitioners, and into the organisational context in which M\&E is now implemented. M\&E is not just the subject of scholarly endeavour, but is practiced on a daily basis and therefore the intersection of theory and practice invites close examination to identify issues, gaps and opportunities for future development.

\section{Evaluation models}

Before exploring four well-known evaluation models in an attempt to explore RQ 1, it is important to provide a brief overview of evaluation theory as context. Evaluation theory in based in theory of change and program theory, which were developed in the 1970s and 1980s in the field of public administration. Key authors include Suchman (1967), Weiss (1972), Wholey (1970, 1979, 1983, 1987), Bennett (1976), Chen and Rossi (1983), Bickman (1987), Lipsey (1993) and more latterly, Rossi, Lipsey and Freeman (2004). Theory of change and program theory, which include program theory evaluation (PTE) and the use of program logic models, were used to evaluate human service programmes, for example, the delivery of social services and health campaigns. However, the principles were soon applied to a number of other fields with Rossi, Lipsey, and Freeman saying that evaluation based on program theory and theory of change is "useful in virtually all spheres of activity 
in which issues are raised about the effectiveness of organized social action" and specifically note its relevance for advertising, marketing, and other communication activities $(2004$, p. 6).

The various stages and elements of program theory are displayed in program logic models and most well-known public relations evaluation models in use today are recognisably reflective of early program logic models, although there is considerable variation.

The Kellogg Foundation (1998/2004) and the University of Wisconsin Extension program UWEX model (Taylor-Power \& Henert, 2008, p. 4) are widely used examples of program logic models for planning and evaluation with the Kellogg Foundation model breaking down programmes into five stages - inputs, activities, outputs, outcomes, and impact. Other models identify up to seven stages in programmes by having short, medium and long-term outcomes. Both Taylor-Power and Henert (2008) and the Kellogg Foundation note that there are several logic models and no single one can be seen to be the best. However, there are a number of commonalities in program logic models can be identified.

First, they define the 'logic' of programmes, that is, which inputs and activities lead to the desired outcomes and impact.

Second, all planning begins with identifying objectives - ideally, SMART objectives that are specific, measurable, achievable, relevant to the organisation's strategy, and time-bound.

Third, evaluation research takes three forms and all should be undertaken: formative research occurs before the programme starts to identify the current state of affairs, for example, in public relations, audience attitudes and behaviours. This sets the benchmark against which change can be measured after the communication intervention has taken place, and helps inform programme strategy. Process and summative research take place during and after the intervention respectively. Fourth, programmes should be measured in term of their outcomes and impact, not simply at the level of activity and outputs.

Having explained the origins of programme evaluation, four models that are often cited in the literature and are representative of the broader spectrum of previous and extant models are now explored. The rationale for choosing these four is that they show a historic progression: the first two are early public relations evaluation models from the 1980s and 1990s, with the second two being originated since 2015 and therefore represent contemporary thinking. They are also drawn from individuals and organisations with different backgrounds to demonstrate the range, but also convergence of thinking on the topic. In order they represent the academic, practitioner, public sector and international association perspectives. 
The first model (Figure 1) is that developed by American academics Scott Cutlip, Alan Center and Glen Broom (1985) and called the PII (preparation, implementation, impact) model.

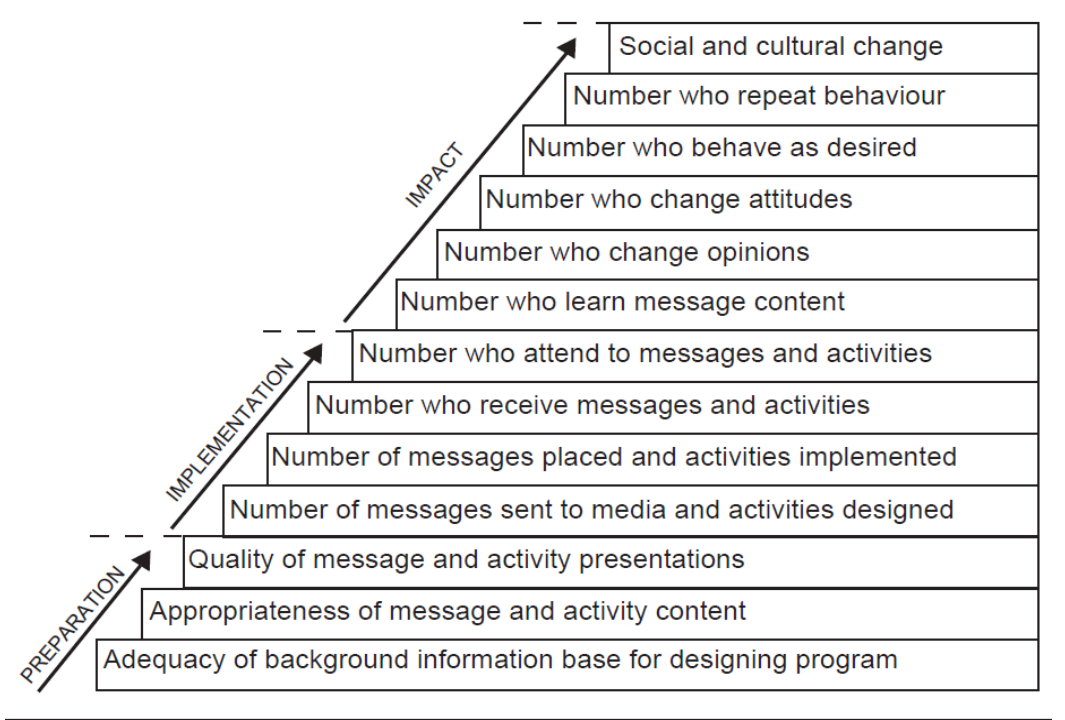

Figure 1. The PII model of evaluation (Cutlip, Center \& Broom, 1985).

While not explicit and using a different format and terminology, the PII model does follow programme logic thinking. Starting at the base of the triangle, a number of progressive steps, beginning with formative research and ending with impacts, can be clearly observed. This model can act as the starting point in judging the direction of thought in evaluation models.

The second model is by US practitioner Walter Lindenmann (1991) (Fig.2) who designed the PR Yardstick model in 1993 (Fig.2) Lindenmann came from the corporate practitioner background having been a researcher for a number of the large consultancies in the USA. 


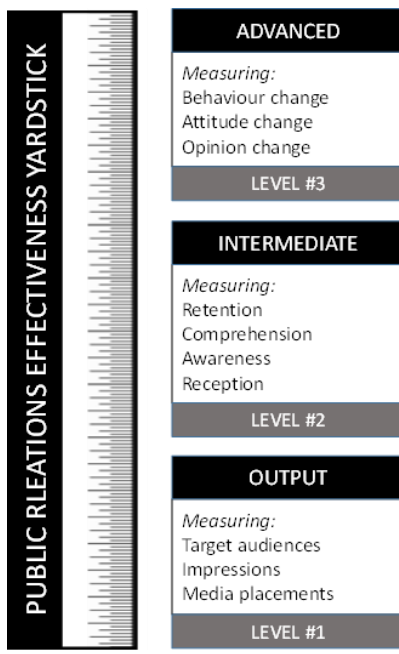

\section{OUTCOMES}

\section{OUTGROWTHS}

\section{OUTPUTS}

Figure 2. The PR Effectiveness Yardstick (Lindenmann, 1993).

In some respects Lindenmann's model is a regression from Cutlip, Center and Broom (1985) in that formative research input is not recognised at all. The evaluation process is seen to commence at the 'output' level and the Intermediate and Advanced stages of his model, while together equating more recognisably to the 'outcome' and 'impact' stages of the programme logic model, do not bear those labels. So, this model advances the evaluation discussion in public relations by introducing programme logic more explicitly, but its use is partial and the terminology eccentric.

These two models, which were widely disseminated in academia and practice at the time and still have currency now, show two interesting differences with implications. First, in terminology, from which there is the source of future confusion and second, in where metrics (measurements) are placed in the stages of the evaluation process, which is still the case.

However, even at this early stage, these models demonstrate some characteristics in common. First, that they are communication process based, that is, they are tracing the progress and desired effects of communication as it moves from the originator to the designated targets of the communication. Second, and linked to the first, the communication is seen to be one way, and in the interests of the originator. Third, it is context neutral: the communication is envisaged as progressing inexorably and there is no recognition that there will be impacts on it depending on context and stakeholder responses.

The third model, produced by the European Commission (Figure 3) was produced in 2015. 


\section{0 political priorities}

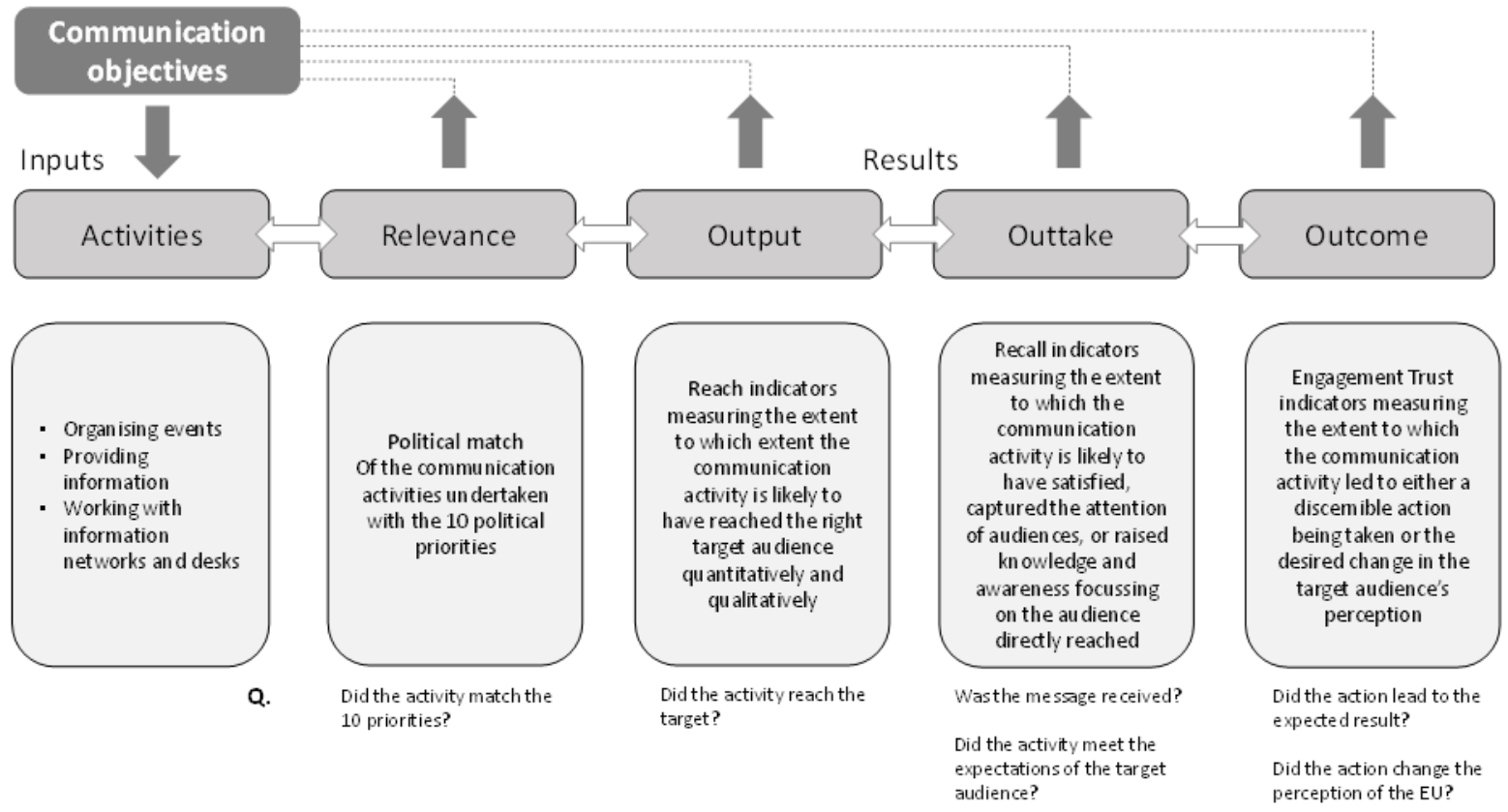

Figure 3. European Commission model (EC, 2015b)

As this paper is being written, the European Commission is still developing its approach to evaluation and the model in Figure 3 represents thinking from the External communication network code of conduct on measurement and evaluation of communication activities (EC, 2015b). Currently the Directorate-General for Communication is using a poster (personal correspondence) in training materials that describes the evaluation process as needs (problem definition), objectives, inputs, activities, outputs, results, impacts.

Both approaches evidence a commitment to programme logic thinking, but the interesting insertion in the 2015 model is relevance. The point here is that communication activity has to demonstrate a match with the political priorities of the Commission. That is still the case, although the term has been dropped from the evaluation poster used in training. Also of note is use of the work outtake which had gained some credence in the intervening years between these models and had, in effect, become the favoured term in place of Lindenmann's outgrowths. Outgrowths as a term has now been expunged by the European Commission, but they are recognisable under both outputs and results.

The fourth model to consider is the on-line, interactive Integrated Evaluation Framework developed by AMEC (2016). The user interface of the on-line tool is shown in Figure 4. 


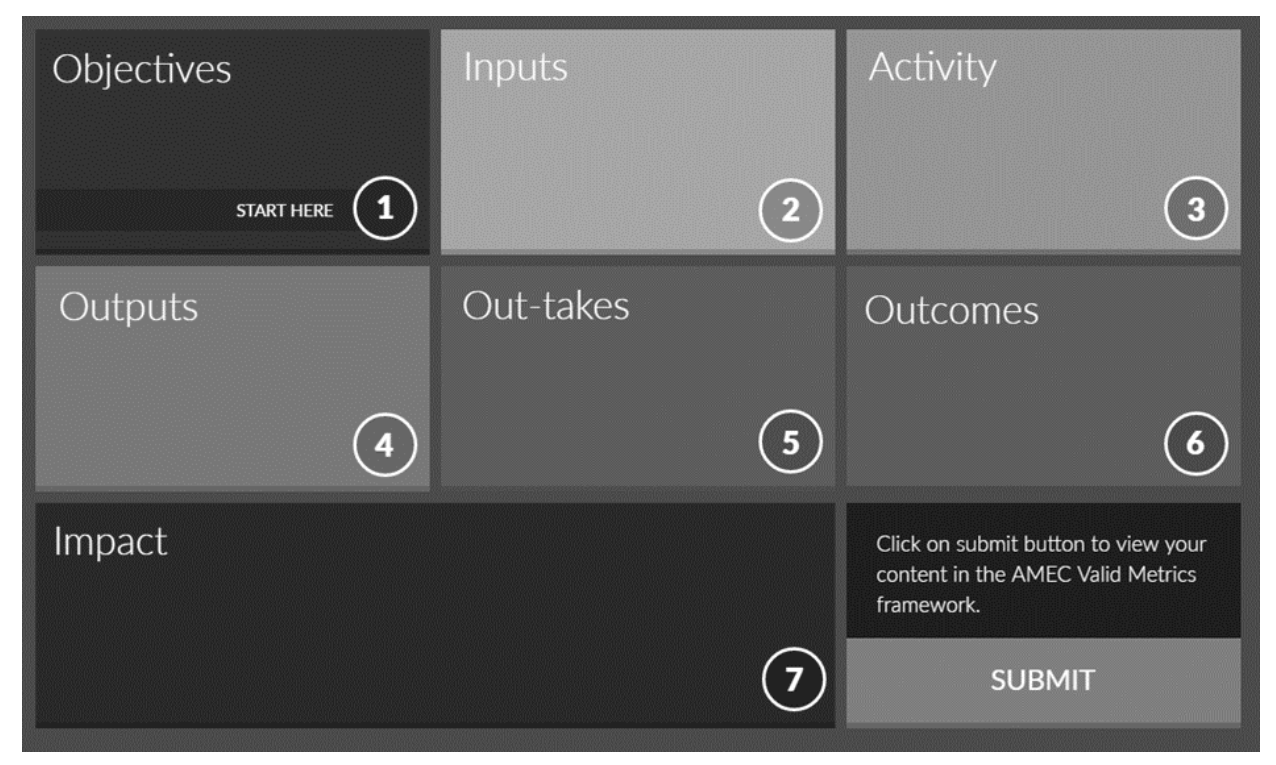

Figure 4. Integrated Evaluation Framework (AMEC, 2016)

The AMEC Framework is an advance in many ways in that it provides users with a range of useful support materials including a guide to producing SMART objectives; a taxonomy showing the stages of the evaluation process, definitions of terms and example metrics and methods; case studies and reading lists.

The Framework clearly shows programme logic thinking and, when the Objectives button is pressed, a drop-down menu invites users to define overall organisational objectives and align communication objectives to these.

Analysis of these last two frameworks shows that the direction of thinking set by the earlier ones, has been continued. Programme logic is the prevailing philosophy underpinning evaluation frameworks; the focus on organisational priorities is explicit; the needs of those who are the object of the communication are not taken into account, although as part of objective setting their current attitudes/opinions/behaviours may be researched in order to change them as the organisation desires; and, no regard is taken of context. They are also, because of the programme logic structure, inherently backward looking and essentially static: once the objective has been achieved, activity halts with little being done to abstract or take forwards any learning generated from the process, successful or otherwise, to inform future decisions.

While the models discussed above summarise the predominant thinking in evaluation, there have been other voices that have sought for a more holistic approach. These voices seek to address some of the issues that have been highlighted above and are not new, although they have not been part of the dominant discourse. 
Macnamara and Gregory (2018) summarise the arguments relating to organisational focus and the lack of reference to legitimate stakeholder interests, but in short, numerous academics have called for public relations to take more account of these imperatives (Dozier, 1992; Hon, 1997; Hon \& Grunig, 1999; L’Etang, 2008; L'Etang, McKie, Snow \& Xifra, 2017; L'Etang \& Pieczka, 1996, 2006; Likely \& Watson, 2013). Notably for this paper, the Public Relations Excellence Theory study of the 1990's (Grunig et al, 2002, 2006) called for evaluation to take place at programme societal, organisational, departmental and programme levels. Gregory (2001) also made the argument for taking context into account.

In response to such calls, Macnamara (2018) developed his integrated model of evaluation (Figure 5) that identifies that there should be a two-way interaction between organisations, stakeholders and society at all stages of evaluation starting with formative research at input through to impact, where not only do organisations make judgements about their impact on stakeholders and society as a result of their communication acts, but so do stakeholders and society more generally, and these latter make these judgements known.

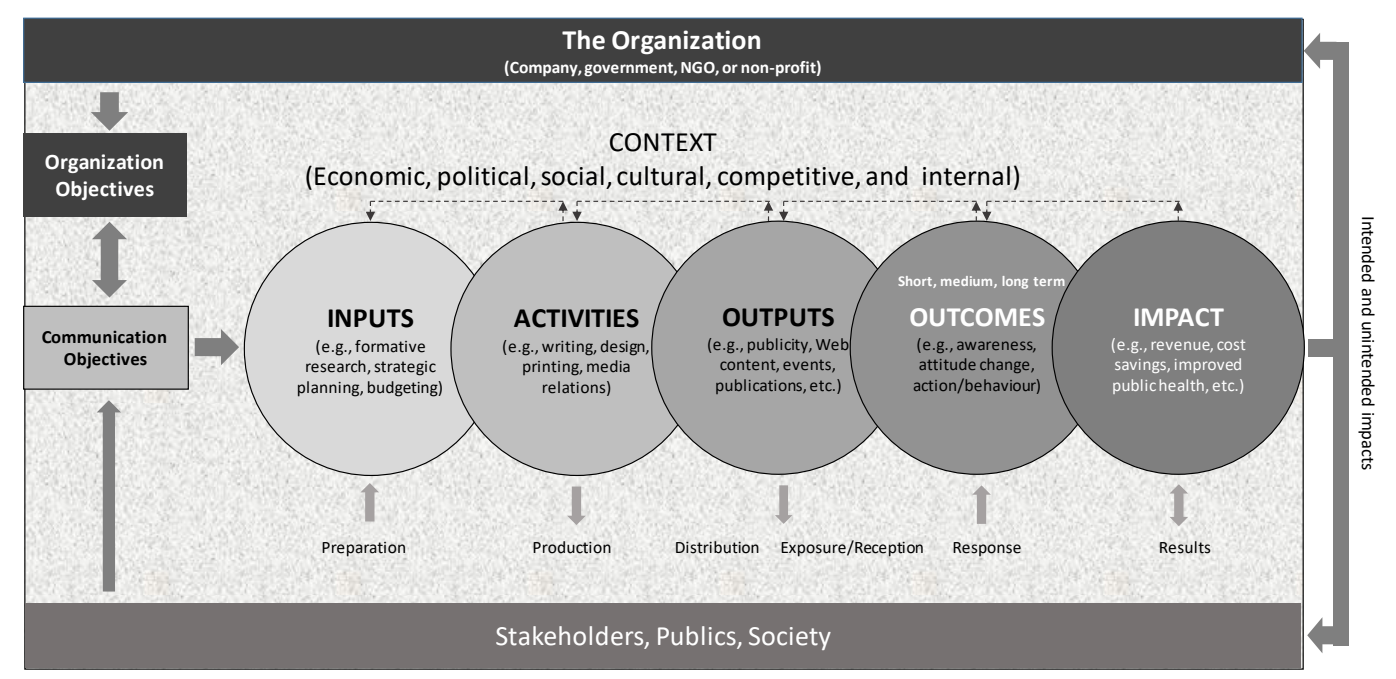

Figure 5. Macnamara's (2018) integrated evaluation model.

The model recognises the importance of context in two respects: the internal (endogenous) factors that affect public relations impacts such as organisational culture, resources and changes in leadership, and the external (exogenous) environment including social, political, economic and competitive dynamics, which are constantly in flux. The arrows emphasise that evaluation involves examining the flow of information and feedback from stakeholders, publics and society to the organisation, as well as from the organisation to its external 'targets'. The bi-directional arrow also indicates that impact is a two-way (e.g., what has been the impact on the organisation as well as on stakeholders, publics and society, including unintended as well as intended impact). This can include 
evaluating side effects and negative effects on stakeholders and evaluating how the organisation has changed to meet the expectations and needs of stakeholders and society.

Thus, it is apparent that although the prevailing direction of thought favours programme logic based, linear models of public relations evaluation, there are alternative voices that call for recognition of contribution beyond the programme level and where stakeholder and societal interests are factored in.

\section{Contemporary management thinking}

The strategic management literature is vast, and it is not within the scope of this paper to provide a full review of how thinking on organisational strategy has developed over the last 40 years. There are many management texts that provide overviews of the management and organisational literature and approach (Grant, 2016; Johnson, Whittington, Scholes, Angwin \& Regner, 2017; de Wit, 2017). However, a number of key themes are identified that are relevant to the purpose of the paper.

Management thinking has moved considerably in the last 40 years. Previous to this time, businesses were seen as largely economic units whose priority was to create profit. The thinking was typified by Milton Friedman and encapsulated in his famous article for The New York Times magazine The social responsibility of business is to increase its profits. (Friedman, 1985). As Antonio Tencati and Laszlo Zsolnai (2009) put it "economic efficiency has become the greatest source of social legitimacy for business" (p.369). Michael Porter's book (Porter, 1989) on competitive advantage of about the same time was seminal. In it, the pursuit of a favourable position in relation to competitors is propounded. The concept is multifaceted and not only includes attracting more customers, but also skilled staff, financial support and/or social acceptability. Competitive advantage applies equally to private, public or not-for-profit organisations. There are many theories about how competitive advantage can be gained, but one that still has currency is the Resource-Based View (RBV) of organisations (Barney, 1991). RBV sees organisations as 'bundles of resources' which, if configured and strategically deployed provide a unique competency base that is rare, non-substitutable, difficult to imitate and of value and this is its source of competitive advantage. Embraced within competitive advantage thinking is the notion that somehow an organisation can impose itself on others and its environment by taking control of the complex forces that are exerted on it. 
The notion of control comes to the fore in concepts such as strategic control (Schendel \& Hofer, 1979), where strategy is implemented as planned and the results are those that were intended. Schreyoegg and Steinmann (1987) in their critique of such thinking, note that to survive organisations have to continuously review their strategies and adjust them. To do this they need to receive constant feedback a) at the point of making initial assumptions, b) during strategy implementation and c) they need to monitor the internal and external environment constantly to detect any changes that are material to the achievement of strategic objectives.

In similar vein, Henry Mintzberg eschewed the idea that strategy can be deliberate, i.e. implemented as planned, but that it is emergent depending on context (Mintzberg, 1978, 1979; Mintzberg \& Waters, 1985).

Freeman (1984) was the first to fully articulate the idea of stakeholding. He took the view that organisations had responsibilities beyond those to shareholders and that those individuals and groups who were affected by or can affect the organisation were to be regarded as having a stake. Whether that is legitimate or not is another question, but the fact is that organisations are not in control of their own destiny, others grant their 'licence to operate', make judgements about whether their activities are legitimate and determine whether they survive in the long-term.

Since his seminal book, Porter has modified his position to one where creating 'shared value' has taken on significant importance (Porter, 2011). In this more recent work, Porter recognises that the relationship between business and society has to be re-conceived and that business need to 'reconnect company success with social progress'.

Referring back to the RBV, stakeholders can therefore be regarded as unique and crucial assets for the organisation: they are sources of intelligence, can generate ideas for new products and can be advocates. An alternative is that they can be regarded as a problem in that they can slow down or halt management aspirations by questioning or opposing them. Either way, understanding the view of stakeholders is vital if organisations are to understand what their future options are, therefore a collaborative way of working is not only sensible, but strategically intelligent.

More recent advances in the management literature have furthered the ideas of cooperation in strategy formulation and implementation. Scharmer and Kaeufer (2010) in U Theory, state that managers can deal with complexity and envisage new futures by divesting themselves of the past, observing deeply what is going on in the present and connecting themselves to best possible futures by quickly developing prototype ideas, receiving feedback and through an iterative process, achieve 
desired results. They see this as a thoroughly collaborative process, using the terms co-sensing, copresencing, co-creating.

Matzler, Fuller, Hutter, Hautz \& Stieger (2014) propose the notion of participatory strategy that advocates wide stakeholder engagement to develop and operationalise strategy. Indeed, they call for new approaches that democratise strategy and refer to open and open-source strategy=making, arguing that social media is a mechanism that can be used to facilitate this.

The concept of organisational agility and agile planning (Sutherland, 2014; Denning, 2016a, 2016b; Rigby, Sutherland \& Takeuch, 2016) has emerged in the $21^{\text {st }}$ century as a turn away from the command and control structures prevalent in earlier generations. Agile is an umbrella term for a range of management practices that promote adaptive planning, continuous improvement and rapid innovation. It is based on self-organising, cross-functional teams and often includes collaborators outside the organisation.

In sum, the management literature has for some time moved away from idea of an organisation being self-contained and in control of its own destiny. Static ways of thinking have given way in the face of the reality that organisations are part of eco-systems: dependent on others, prone to the vagaries of rapidly changing contexts and driven by new realities such as globalisation, the power of new technologies and the pace of change.

Turning to the professional business environment, there are observable changes that reflect these new realities. In the public sector, participatory and deliberative policy and decision-making where citizens are actively involved in decisions that affect their communities and national life, are no longer novel. Citizens' summits, panels and juries, participatory budgeting, collaborative design of physical spaces, deliberative workshops, national consultation are now a regular part of the democratic process.

In the business world too, new initiatives such as Integrated Reporting are gaining ground, where organisations voluntary report against six 'capitals', only one of which is financial. Together these capitals show how its "strategy, governance, performance and prospects, in the context of its external environment, lead to the creation of value in the short, medium and long term" (IIRC, 2019). One of the six capitals is social and relationship and relates to shared norms, common values and behaviours, key stakeholder relationships and the maintenance of the social licence to operate.

More generally, there are copious media stories of organisations being held to account for corporate malfeasance or practices that are not socially acceptable: VW over the diesel emissions scandal, Facebook for selling personal data, cigarette manufacturers for encouraging women and young 
people to smoke in developing nations. It is interesting to observe that not all these scandals concern organisations breaking the law, but about contravention of societal expectations.

The public relations literature has embraced a number of these more recent concepts from the management literature as Macnamara and Gregory (2018) identify, among them participation (Falkheimer \& Heide, 2015; Torp, 2015), agility (van Ruler, 2016), emergent communication strategy (King, 2010), and there is a long standing recognition that communication involves a two-way dynamic interaction from the dialogic, rhetorical and post-modern schools of thinking.

It appears strange then that the more well used evaluation models, including the first four presented at the beginning of this paper, do not reflect these advances. They remain resolutely organisationally focused, uni-directional and oblivious to stakeholder interaction and context. Furthermore, they are progressively more complex: they contain more steps, an increasing number of indicators, metrics and measures. They require a taxonomy to explain the various terms and seem designed, as Murray and White (2005) found in their research with CEOs, to be an exercise in self-justification rather than an aid to enlighten management or an aid for future decision-making.

Macnamara's (2018) model, while based on programme logic, extends thinking considerably by taking account of stakeholders and context as active actors in the communication process. This is new and advances theory and practice significantly, but it too can be criticised for adding layers of complexity, particularly in the accompanying 'taxonomy' of metrics and methods.

In answer to RQ1, what can be drawn from the observations so far is that there is a disconnect between the most used public relations models and the advances in management practices and academy. This would partially explain why public relations practitioners do not use, or do not fully use, the models because they are complex, resource intensive, cumbersome to use and not appreciated by those who ultimately judge performance. They are not amenable to the realities of modern practice which is time-pressured, resource-lean and held to account for future as well as past performance.

What also comes from this analysis is that management is not especially interested in the product that comes from this intensive labour. It does not answer the perennial 'so what?' questions of senior managers: 'So what should I do now' and 'so what should I do in the future?

To answer RQ1, it appears there is a discernible 'direction of travel' in public relations measurement and evaluation, but it cannot be claimed that it is gaining significant traction with management.

The next section of this paper will look specifically at addressing RQ2. So far the reasons why senior managers do not appear to be interested in the evaluations practitioners undertake have been 
explored. So the question has to be asked, 'is there a better way to evaluate that does attract their interest?'

\section{A way forwards.}

Many senior managers are trained in business schools. Not all have degrees in business, but they will have at some stage engaged with management courses or at least taken in-house training that schools them in the ways and language of business. They know about finance, strategy, corporate planning, operations and the like and will have connected with the prevailing theories and trends in thinking about business and organisations.

One of the challenges faced by public relations practitioners that has long been recognised is that they do not understand or speak the language of business (Murray \& White, 2005). As has been indicated earlier, the evaluation processes that are often used in public relations do not present information or use language that is familiar to most senior managers. Although practitioners may use programme logic models to present their measurements and evaluations that may be familiar to senior managers, the content of those evaluations such as OTS, click throughs etc. will be alien to them. In addition and in reality, they care less about activity, inputs and outputs that often occupy the bunk of the content of evaluation reports. Bluntly put, they care more about outcomes and results that impact on the organisation, that help them in future decision-making and that help them address the many accountabilities they face. If then, practitioners are able to focus on these things, they may be able to demonstrate their worth more readily.

Furthermore, as detailed above, the world has changed from one where organisations can impose themselves on their environment to one where they are accountable to it. That is not to say that organisations cannot develop purposeful strategies, but the way that is done must be in a collaborative, agile and accountable manner. Communication strategies that aim to support these ambitions should follow suit: indeed strategy can only be realised through communication since communication is at the heart of organisation and organising as both public relation and strategic management scholars agree (Gregory \& Willis, 2013; Putnam \& Nicotera, 2009; Rouleau \& Balogun, 2011; Zerfass, 2008). Any public relations evaluation model that determines whether an organisation has been successful or not in its communication endeavours, has therefore to reflect the characteristics of contemporary business thinking to gain the right to be heard. 
A number of public relations academics have developed ways of mirroring the ways that senior managers think about strategy. Moss (2011), developed the C-Macie model linking the two. Grunig et al.'s $(2002,2006)$ work hints at this in offering the four levels of contribution: societal, organisational, programme and individual. However it was the South African Benita Steyn (2004, 2007) who articulated at a detailed level that strategy is considered at a number of levels: enterprise, where the organisation's overall relationship with society and issues of legitimacy are addressed; corporate, which concerns the resources, mainly financial of the organisation; business unit, where the market is the primary concern ; functional, where the contribution of each functional area is considered; and, operational where strategy is developed into operational projects and plans. Linking recognised ways of developing and enacting strategy to public relations work offers a rich way forwards in breaking through to senior manager consciousness. In further developing this thinking Gregory and Willis (2013) have created a model (Fig. 6) that takes the levels of strategy and applies a public relations lens to them. The driving question in the thinking behind their model is 'what does an organisation have to do in order to maintain its legitimacy and thrive?'. The question is addressed by identifying which stakeholders are in play at each level of strategy and how the organisation may engage with them to ensure sustainability. In short, the model requires a $U$ turn in thinking about evaluation. The premise is that far from organisations being in a position where they can see through communication effects via increasingly complex processes based on programme logic, the impact of an increasingly volatile context and the power of stakeholders to affect organisations, means that evaluation has to be viewed from the other side of the telescope too. The question is not only 'have we achieved our objectives', but also 'have we discharged our accountabilities?'.

The existing models do not accommodate this dual perspective: they are largely representative of old command and control and deliberate strategy thinking where the organisation determines a way forward through pre-determined objectives and expects the results to be as planned. Any evaluation is therefore, inherently backward looking, blind to potential opportunities and threats and does not provide senior managers with the information they need to secure their ongoing licence to operate and to flourish. Such models are increasing mired in ever more extensive lists of indicators and metrics as the number of communication channels, content generation technologies and platforms proliferate and the amount of resource required to maintain each stage of the process is difficult to justify, especially if senior managers do not find the results helpful.

A move to a model that clearly links communication to strategy and operates at the level of principles rather than a proliferation of metrics, allows each organisation to adapt the principles to 
their particular situation, facilitates agility because it presumes close contact with stakeholders and co-production with them, and an ability to respond to the ever shifting context because the organisation recognises it is part of an eco-system whose purpose is to contribute to that system, not only attend to its narrow organisational interests.

Principles-based ways of operating are common. For example, in the public relations field, the Global Code of Ethics promoted by the Global Alliance (GA) (GA, 2018), the confederation of public relations and communication management associations worldwide, use this approach, recognising that practitioners have different ways of working and operating in varied contexts around the world. A principles-based approach allows them to apply the Code as their situation requires.

The Gregory and Willis (2013) model shown in Figure 6 can be adopted for use in evaluation and turned into a principles-based process by linking a number of key questions to each level of strategy.

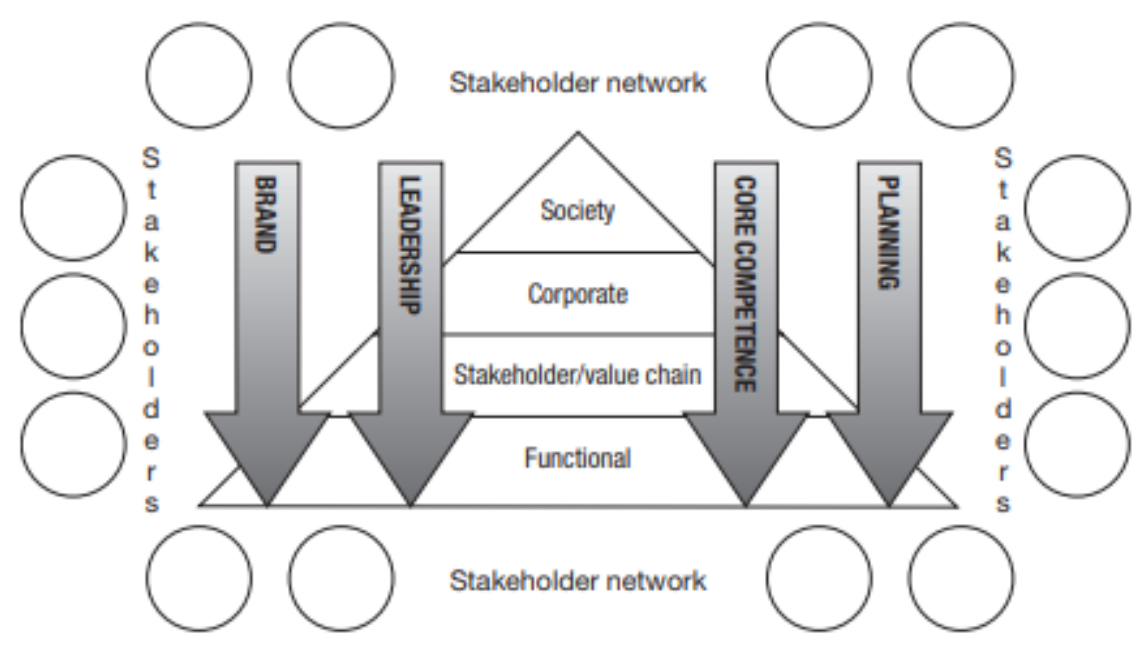

Figure 6: Gregory and Willis' (2013) four-by-four model of strategic public relations.

First, it is important to explain the model briefly. The four elements in the pyramid represent the organisation, split into the different levels of strategy at which it operates. The circles represent the various stakeholder communities on which it depends, but this is a constantly dynamic network permeating and connecting with the four organisational levels. Stakeholders are shown as a network because organisations have several, are ultimately dependent on them, and are held in a web of relationships with and by them, whether they be internal or external to the organisation. Together these networks represent society - the ultimate context in which organisations operate. As Starck and Kruckeberg (2001) said" "Corporations ultimately operate by consent of society, which 
remains in fact the ultimate stakeholder". They are also shown as a network because the reality is that organisations are pulled towards different stakeholders at different times and with different intensity depending on context. The eco-system is dynamic and there are different forces in play at any one time that force re-configurations. For example, after the global financial crisis banks were pulled closer to regulatory and governmental stakeholders as those bodies sought to exert greater power over them. The stakeholder network has a tension, rather like a spider's web, with the organisation seeking equilibrium between the competing demands of a range of interconnected stakeholders.

The four vertical arrows represent the four distinct attributes of exemplary public relations and permeate all the levels. These attributes are (1) an excellent understanding of the brand; (2) exhibiting and supporting leadership; (3) embedding public relations as a core organisational competence, and (4) excellence in planning, managing and evaluating public relations. There is no significance in the fact that the arrows point downwards beyond that they permeate all levels.

It is the four levels that offer the opportunity to re-think evaluation, since it is the strategic contribution that is made at each level that counts in this context.

Table 1 represents the model at each level, with, on the left an explanation of each level and on the right the key questions that need to be asked that embody the key accountabilities that the organisation has. These key questions serve as Key Performance Indicators (KPIs) the answers to which can be the evaluation of the performance of public relations work. 


\begin{tabular}{|c|c|c|c|}
\hline $\begin{array}{l}\text { Stakeholders holding } \\
\text { to account }\end{array}$ & Levels of strategy & Key evaluation questions & $\begin{array}{l}\text { Accountable role of public relations } \\
\text { (evaluation principles) }\end{array}$ \\
\hline $\begin{array}{l}\text { Society as a whole and the } \\
\text { contextual factors } \\
\text { impacting on it }\end{array}$ & Society & $\begin{array}{l}\text { What is our role in society? } \\
\text { (Purpose and legitimacy) } \\
\text { Do we discharge our expected } \\
\text { obligations in a way that is } \\
\text { acceptable? (Values and } \\
\text { behaviour) }\end{array}$ & $\begin{array}{l}\text { Contextual awareness. Assisting in } \\
\text { developing, negotiating and } \\
\text { communicating purpose, monitoring its } \\
\text { acceptance, feeding back intelligence to } \\
\text { leaders. } \\
\text { Monitoring reputational indicators, acting } \\
\text { as ethical guardian, being the } \\
\text { organisational interlocutor. }\end{array}$ \\
\hline $\begin{array}{l}\text { Board and senior } \\
\text { management. } \\
\text { Internal stakeholders. }\end{array}$ & Corporate & $\begin{array}{l}\text { Are we deploying our } \\
\text { resources effectively and } \\
\text { efficiently? } \\
\text { Are senior managers making } \\
\text { informed decisions? } \\
\text { Are senior managers } \\
\text { articulating decisions well? }\end{array}$ & $\begin{array}{l}\text { Advising on communication 'capitals'. } \\
\text { Providing stakeholder perspectives on } \\
\text { potential decisions and communicating } \\
\text { decisions. } \\
\text { Coaching senior managers }\end{array}$ \\
\hline $\begin{array}{l}\text { Those stakeholders in } \\
\text { regular contact with the } \\
\text { organisation such as } \\
\text { regulators, customers, } \\
\text { suppliers and internal } \\
\text { stakeholders }\end{array}$ & Value chain & $\begin{array}{l}\text { Does the organisation work } \\
\text { collaboratively to meet its } \\
\text { legitimate objectives? } \\
\text { Does the organisation act in a } \\
\text { way that builds trust? }\end{array}$ & $\begin{array}{l}\text { Advising on and undertaking collaborative } \\
\text { communication best practice. } \\
\text { Advising and coaching colleagues on good } \\
\text { relationship building. Advising on handling } \\
\text { of conflicting stakeholder agendas. Acting } \\
\text { as the ethical guardian. }\end{array}$ \\
\hline $\begin{array}{l}\text { Colleagues within the } \\
\text { organisation }\end{array}$ & Functional & $\begin{array}{l}\text { Does the PR team act to the } \\
\text { highest operational } \\
\text { professional standards and } \\
\text { practices? } \\
\text { Does the PR Team deliver the } \\
\text { results they have promised? }\end{array}$ & $\begin{array}{l}\text { Ensuring the team is fully up to date with } \\
\text { best practices. } \\
\text { Developing, implementing and evidencing } \\
\text { effectiveness based on agreed outcomes. }\end{array}$ \\
\hline
\end{tabular}

Table 1: Types of stakeholders and accountabilities at each level

The following offers an explanation of these levels and how evaluation takes place.

At the level of society an organisation seeks to obtain legitimacy for itself by trying to gain and maintain support from society as a whole. Society represents the context in which the organisation operates including the economic, technological, political and social environment and embodies those norms that characterise interactions. An organisation's place, standing and reputation in society determine whether its 'licence to operate' is granted and supported and a measure of that is public opinion on it. Here its purpose and direction is constantly assessed. Values, as expressed in it decisions, words and actions are also put to the same test and either found true or wanting

Public relations should play a central role in helping to clarify the organisation's values and purpose by testing (ideally co-creating) them with those at the stakeholder level (including the critical ones) as being the representatives of society, and being informed about social norms and context. The 
quality of that intelligence can be evaluated qualitatively and verified independently. The public relations department should also monitor the way the organisation goes about (behaviour) achieving purpose to determine whether they are acceptable to society generally. This again can be evaluated by testing the veracity of practitioners' judgements.

Public relations also has a role in promoting the organisation by the clear communication of its values and purpose and demonstrating consistency of performance against them and their effectiveness at doing this can be readily assessed through qualitative research, with the ultimate question being reputation, which is society's qualitative judgement on the organisation.

At the corporate Level, organisations largely focus on financial and business goals. This is where the resources of the organisation are marshalled and the form and structure of the organisation is decided in support of its purpose. Here organisational efficiency and effectiveness becomes the focus. Apart from the more obvious resources that have to be in place such as financial, human, technological, estate and so on, as Laurati (2008) and the IIRC (2019) argue, the cognitive and behavioural resources of the organisation also have to be secured. There are three elements to this. First, the organisation has to ask if it has the reputation it needs in order to pursue what it aspires to do. Second, the organisation will need to ensure it has the relationships that it needs to achieve its objectives. Third, the culture of the organisation needs to be is aligned to what it wishes to promote externally, or it will not succeed.

Evaluating reputational, relational and cultural capital and the value of intangible assets (worth $87 \%$ of the value of the organisation according to the IIRC (2019)) then becomes the accountability for public relations since that is what their stakeholders at this level demand.

The public relations area can make another critical contribution at this level. It can support management in making informed choices by ensuring that multiple-stakeholder perspectives are taken into account when resource decisions are made. So, for example, if maximising shareholder return is always prioritised above all other stakeholders' legitimate claims, the organisation will create issues. The interest of all stakeholders must be properly balanced within the declared value base. It is also public relations' role to provide intelligence to senior managers on how the organisation's corporate decisions are likely to be perceived by stakeholders and to involve relevant stakeholders in, and inform them of, corporate level decisions as appropriate.

The quality of the advice given to senior managers on choices at corporate level can be readily evaluated through qualitative research with that stakeholder group. 
It is recognised that it is neither desirable nor possible for the public relations function to be totally responsible for all the organisation's relationship-building and communication activity. An essential role of the senior public relations professional at the corporate level is to coach and mentor other senior managers in communicating their informed objectives and decisions to their peers and relevant stakeholder groups, and ensuring that they too are alert to the reputational, relational and cultural opportunities and threats inherent in doing so.

At the value-chain level, those stakeholders directly involved in and with the organisation are the focus. Their closeness to the organisation distinguishes them from societal stakeholders, although they are part of society. Typical value chain stakeholders will include customers, service users, delivery partners, suppliers, distributors, regulators, employees etc. It is at value chain level that organisational intentions and decisions are made real by being operationalised. The public relations function has a part to play in engaging with these 'close' stakeholders, including those who may be regarded as troublesome, such as activist on-line communities. This engagement could take a variety of forms: to work with them to -co-create a future; to keep them informed of developments, to persuade them to buy or to sell, to identify and work through their current and future concerns, to identify potential issues and crises, to co-develop opportunities they raise, to solve common problems and so on. Specific functional expertise in identification, profound understanding of stakeholders and engagement can be offered by public relations alongside coaching and mentoring other non-functional specialists who interact with these stakeholders. In addition, the public relations function can offer help in detecting, balancing and managing what could well be the conflicting demands of different stakeholder groups and navigating complex relationships between them and the organisation.

As indicated earlier, being cognisant of any differences between internal culture and behaviours and external expectations of that culture and behaviour is crucially important at this level. All employees are representatives of the organisation and how they behave and communicate will constitute their articulation and enactment of the whole organisation.

Evaluation at this level can be both quantitative and qualitative. The number of interactions is important, in that it should be appropriate to maintaining healthy relationships, but equally important is the quality of relationships. Purely instrumental relationship aimed at just furthering organisational objectives are problematic, although transactional relationships are perfectly acceptable where that is the purpose of the contact. However, the aspiration at this level is for longer term-relationships that are for mutual benefit, therefore it is the quality of the relationship 
that needs to and can be measured (Hon \& Grunig, 1999) since this is crucial again to the intangible asset base of the organisation and will permit it to pursue its objectives.

At the functional level, firstly, it is the role of public relations to liaise with the other specialist functional areas of the organisation to determine how its specific communication skills can assist all functions in the organisation with their communication responsibilities so that they too can fully realise their functional purpose and objectives at an operational level. This will involve coaching and mentoring colleagues throughout the organisation to be "communicatively competent" so that they can undertake public relations tasks themselves, or enlist the help of the specialists when needed. Secondly, as a specific function, the public relations department will engage in planning and delivering programmes and campaigns in support of overall organisational objectives. This will involve using recognised business disciplines and public relations best practice to design effective plans embracing the full range of contemporary communication techniques. It will also involve moving seamlessly between reactive, pro-active and interactive roles depending on requirements.

The evaluation of effectiveness at this stage may utilise some of the programme logic steps outlined earlier in this paper, but the emphasis will be on the last two stages, results and impacts, not on the process elements of inputs, activities and outputs, which appear to be the current obsessions of many practitioners. It is salutary to note, that the metrics and indicators are relatively few at the later end of the process and honing these down to what the key accountabilities are and generating a few Key Performance Indicators would put focus and value on the evaluations produced. Hence, the strategic intelligence that comes from conducting evaluations at this level, with its emphasis on informing future decision-making is crucial. What has been achieved is important to note, but what is abstracted from both successful and unsuccessful interactions and campaigns is much more important.

Figure 7 illustrates the thinking in visual form, but re-orders the levels from the Gregory and Willis (2015) model and adds one more, campaign, which separates the two roles highlighted under functional level above. In place of corporate in the Gregory and Willis model (2015), organisation is used instead. In the upward arrow, organisational objectives and imperatives are shown to be rooted and grow from within the organisation but, importantly, moves beyond the organisational level to take into account stakeholder concerns and interests and seek to make a contribution to society. Thereby longer-term sustainability and legitimacy is embedded into evaluation thinking. The downward arrow denotes the societal and stakeholder realities of 'holding to account' being factored into corporate decision-making (the organisational level) and this being carried through at 
the operational level of public relations departments and campaigns as those decisions are implemented. The key questions provided in Table 1 above still apply

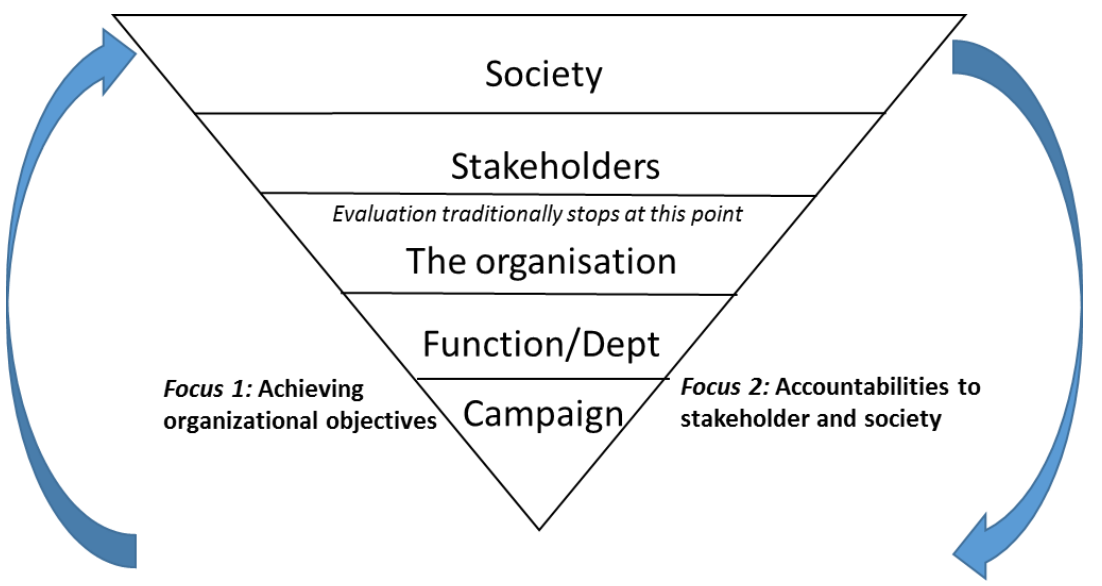

Figure 7. The bi-directional and bi-functional evaluation model: the achievement of organisational objectives and maintenance of legitimacy, and the exertion of stakeholder and societal influence to influence organisational strategy and operations.

In summary, this approach offers both a holistic and contemporary approach to measurement and evaluation that operates at a range of levels and offers a holistic approach to organisation-wide public relations evaluation. It also focusses on outcomes, not process from the outset. It is concerned with the progress of communication and with organisational legitimacy and sustainability as bestowed by stakeholders and society. It informs decision-making and is embedded in strategymaking and enactment. Finally, it provides senior managers with real-time information that is also future-oriented. For these reasons it offers a compelling answer to RQ2 and a practical way forwards.

\section{Conclusions and avenues for further research}

This paper has traced the approach of evaluation initiatives over the last 35 years. It has found that programme logic models predominate and that these have become more sophisticated and complex over the years to the point where there needs to be pages of guidance on taxonomies, indicators, metrics and measures. This is indicative of a 'command and control' approach to evaluation that regards communication as a process that can be atomised and rolled out as planned. A key criticism 
of these models is a suspicion that they are more concerned with justifying public relations work than about providing useful information on performance and actionable intelligence that will inform future decision-making.

Running in parallel to what can be described as an evaluation 'industry' based on such models (since many consultancies and specialist agencies have vested interests in their promotion because they make significant revenues from them) and gaining more attention in the public relations literature over time, concerns about the organisational-centricity and lack of attention to the broader context in which public relations operates has come to the fore. More recent public relations evaluation models have given some attention to these matters.

At the same time, the management literature has progressed thinking about strategy and decisionmaking processes from a position where the organisation undertakes planning internally and expects strategy and decisions to be enacted as planned, to one where profound attention is given to context and where external (and internal) stakeholders participate and help shape direction. This has been accompanied by an understanding that society demands accountability for their organisational actions, not just to perform well financially, but to contribute and report across a range of 'capitals'.

This paper responds to these discussion by calling for an evaluation process that also considers the accountabilities that organisations have to various stakeholder communities, including demonstrating their contribution to society since it is from society that they seek a licence to operate. In doing so it flips the logic behind many evaluation models that 'follow the communication' to one that demands that they 'follow the accountability' too. It changes the focus from an internal concern about process to an external one that centres on legitimacy and value. It advocates a principles-based evaluation that finds its locus around a number of key questions, the answers to which can form a limited number of KPIs against which public relations can be evaluated and judged. These KPIs not only provide information on the performance of the function, but of the organisation because at the heart of organising and organisations is communication. Furthermore, such an approach will generate essential intelligence for senior managers, whose ultimate responsibility is to ensure to sustainability of their organisations. It answers questions about the value that public relations adds to organisations, and ultimately that is what evaluation seeks to do.

This new approach adds to theory building in two respects: first it offers a new approach to mainstream thinking in public relations evaluation that is not based on programme logic. Second, it makes the case from moving away from metrics and indicators to a principles-based approach based on key questions. In doing so it offers a new direction in evaluation that may provide the way to 
breaking through the current incremental improvements in theory. At the same time it offers a new way forward for the practice, which is not gaining the traction it requires by using the prevailing models.

This 'flipping' of the usual approach opens up a number of avenues for future research: first, further development of questions that set the KPIs for public relations performance and value. Second, elaboration of an approach external to the organisation to evaluation that takes stakeholder stand points. Third, articulation of both the external and internal approaches to develop a comprehensive evaluation picture. Fourth, it is recognised that this paper looks at evaluation at the macro level and does not explore in detail the short-term and singular publicity campaigns that make up much practitioner work and as embraced in Watson \& Noble's (2014) Short-term and Continuing model. The development of the Key Questions approach as argued here could be a fruitful line of enquiry for these kinds of activities.

The paper also issues a number of challenges to those who wish to develop the programme logic approach: firstly, instead of producing proliferating lists of indicators, metrics and measures, how will the process be simplified to make it more manageable? Second, as other less tangible elements are added to programme logic models, such as context and stakeholder perspectives, how can sensible measurements be established in all parts of the model? Third, how can actionable intelligence that goes beyond the bounds of programme evaluation be accommodated in such models?

If, as Pawson and Tilley (1997) claim, the main aim of evaluation research is to understand what works better, for whom, in what circumstances, and why, then the approach recommended in this paper answers that call in a holistic, comprehensive, but parsimonious way.

\section{References:}

AMEC (Association for Measurement and Evaluation of Communication). (2015). Barcelona principles 2.0. London, UK: Author. Retrieved from http://amecorg.com/barcelonaprinciples-2-0

AMEC (Association for Measurement and Evaluation of Communication). (2016). Integrated evaluation framework. London, UK: Author. Retrieved from http://amecorg.com/amecframework

AMEC (Association for Measurement and Evaluation of Communication). (2017). Integrated evaluation framework. London, UK: Author. Retrieved from http://amecorg.com/amecframework

Barney, J. (1991) Firm Resources and Sustainable Competitive Advantage, Journal of Management, 17(1), 99-120. 
Baskin, 0., Hahn, J., Seaman, S. \& Reines, D. (2010). Perceived effectiveness and implementation of public relations measurement and evaluation tools among European providers and consumers of PR services. Public Relations Review, 36(2), 105-111

Bennett, C. (1976). Analyzing impacts of extension programs, ESC-575.Washington, DC: US Department of Agriculture Extension Service. Department of Agriculture, Extension Service.

Bickman, L. (1987). The functions of program theory. In New Directions for Program Evaluation, 33, 5-18. San Francisco, CA: Jossey-Bass. https://doi.org/10.1002/ev.1443

Chen, H. \& Rossi, P. (1983). Evaluating with sense: The theory-driven approach. Evaluation Review, 7(3), 283-302. https://doi.org/10.1177/0193841X8300700301

Cutlip, M., Center, A. \& Broom, G. (1985). Effective public relations (6th Ed.). Englewood Cliffs, NJ: Prentice-Hall.

Denning, S. (2016a). How to make the whole organization "Agile". Strategy \& Leadership, Vol. 44, Issue 4, pp. 10-17.

Denning, S. (2016b). HBR's embrace of Agile. Forbes.com, April 21, 2016.

www.forbes.com/sites/stevedenning/2016/04/21/hbrs-embrace-of-agile/Dozier, D. (1992). The organisational roles of communications and public relations practitioners. In J. Grunig (Ed.). Excellence in public relations and communication management (pp. 327 - 356). Hillsdale, NJ: Lawrence Erlbaum Associates

European Commission. (2014, August). Measuring the European Commission's communication: Technical and methodological report. Brussels, Belgium. Retrieved from http://ec.europa.eu/dgs/communication/about/evaluation/index en.htm

European Commission. (2015a). Toolkit for the evaluation of the communication activities. Brussels, Belgium. Retrieved from https://ec.europa.eu/info/sites/info/files/communicationevaluation-toolkit en.pdf

EC (European Commission). (2015b). External communication network code of conduct on measurement and evaluation of communication activities. Brussels, Belgium: Author. Retrieved from http://ec.europa.eu/dgs/communication/about/evaluation/documents/code-of-conductmeasurement-evaluation-communication-activities_en.pdf

European Commission. (2018). Communication network indicators. Brussels, Belgium: Author.

Falkheimer, J., \& Heide, M. (2015). Strategic communication in participatory culture: From oneand two-way communication to participatory communication through social media. In D. Holtzhausen \& A. Zerfass (Eds.), The Routledge handbook of strategic communication (pp. 337-350). New York, NY: Routledge.

Freeman, R.E. (1984). Strategic Management: A Stakeholder Approach, Boston: Pitman.

Friedman, M. (1985). The social responsibility of business is to increase its profits. The New York Times Magazine, $13^{\text {th }}$ September 1985

GA (Global Alliance). (2018). Code of ethics. Author. Retrieved from https://www.globalalliancepr.org/code-of-ethics

GCS (Government Communication Service). (2016, January). GCS evaluation framework. London, UK: Cabinet Office, Her Majesty's Government. Retrieved from https://gcs.civilservice.gov.uk/wp-content/uploads/2015/11/GCS_GCS-Evaluationframework_A4-_191115.pdf 
Grant, R.M. (2016). Contemporary Strategy Analysis (9 $9^{\text {th }}$ Edition), Maldon, MA: Wiley-Blackwell

Gregory, A. (2001). Public relations and evaluation: does the reality match the rhetoric? Journal of Marketing Communication, 7(3), 171-189

Gregory, A. and Watson, T. (2008). Defining the gap between research and practice in public relations programme evaluation - towards a new research agenda, Journal of Marketing Communications, 14(5) 337-350.

Gregory, A. \& White, T. (2008). Introducing the Chartered Institute of Public Relations initiative. In B. van Ruler, A. Verčič, A., \& D. Verčič (Eds.), Public relations metrics: Research and evaluation (pp. 307-317). New York, NY: Routledge.

Gregory, A. \& Willis, P. (2013). Strategic Public Relations Leadership, London: Routledge.

Grunig, J.E. (1983). Basic research provides knowledge that makes evaluation possible. Public Relations Quarterly, 28(3), 28-32

Grunig, L., Grunig J. \& Dozier, D. (2002). Excellent organizations and effective organizations: A study of communication management in three countries. Mahwah, NJ: Lawrence Erlbaum.

Grunig, J., Grunig, L. \& Dozier, D. (2006), "The excellence theory". In Botan, C. and Hazelton, V. (Eds.), Public Relations Theory II, Lawrence Erlbaum, Mahwah, NJ, pp. 21-62.

Hon, L. (1997). What have you done for me lately? Exploring effectiveness in public relations. Journal of Public Relations Research, 9(1), 1-30. https://doi.org/10.1207/s1532754xjprr0901_01

Hon, C. L., \& Grunig, J. E. (1999). Guidelines for measuring relationships in public relations. Gainesville, FL 32611-8400: The Institute for Public Relations

IIRC (International Integrated Reporting Council). (2019). Retrieved from http://integratedreporting.org/the-iirc-2/

IPR (Institute for Public Relations). (2016). IPR Measurement Commission. Retrieved from http://www.instituteforpr.org/ipr-measurement-commission

Johnson, G., Whittington, R., Scholes, K. Angwin, D. \& Regner, P. (2017). Exploring Corporate Strategy (11th Ed.), Harlow: FT Prentice Hall;

Kellogg Foundation. (1998/2004). Logic model development guide. Battle Creek, MI: Author. Retrieved from https://www.wkkf.org/resource-directory/resource/2006/02/wk-kelloggfoundation-logic-model-development-guide

King, C. (2010). Emergent communication strategies. International Journal of Strategic Communication, 4(1), 19-38. https://doi.org/10.1080/15531180903415814

Laurati, F. (2008). Institutionalising Public Relations. Plenary Panel, European Public Relations Education and Research Association, Milan, October 2008

L'Etang, J. (2008). Public relations: Concepts, practice and critique. London and Thousand Oaks, CA: Sage.

L'Etang, J., McKie, D., Snow, N. \& Xifra, J. (2017). The Routledge handbook of critical public relations. London, UK: Routledge.

L’Etang, J. \& Pieczka, M. (1996). Critical perspectives in public relations. London: International Thomson Business Press. 
L'Etang, J. \& Pieczka, M. (2006). Public relations - critical debates and contemporary practice. Mahwah, NJ: Lawrence Erlbaum Associates.

Likely, F., \& Watson, T. (2013). Measuring the edifice: Public relations measurement and evaluation practice over the course of 40 years. In J. Sriramesh, A. Zerfass, \& J. Kim (Eds.), Public relations and communication management: Current trends and emerging topics (pp. 143-162). New York, NY: Routledge.

Lindenmann, W. (1993). An 'effectiveness yardstick' to measure public relations success. Public Relations Quarterly, 38(1), 7-9.

Lipsey, M. (1993). Theory as method: Small theories of treatments. New Directions for Program Evaluation, 57, 5-38. https://doi.org/10.1002/ev.1637

Macnamara, J. (2015). Overcoming the measurement and evaluation deadlock: A new approach and model. Journal of Communication Management, 19(4), 371-387.

Macnamara, J. (2018). Evaluating public communication: New models, standards and best practice. Abingdon, UK: Routledge

Macnamara, J. \& Gregory, A. (2018). Expanding evaluation to progress strategic communication: Beyond message tracking to open listening. International Journal of Strategic Communication. 12(4), 469-486

Macnamara, J., Lwin, M., Adi, A. \& Zerfass, A. (2015). Asia Pacific Communication Monitor 2015/16: The state of strategic communication and public relations in a region of rapid growth. Survey results from 23 countries. Asia Pacific Association of Communication Directors (APACD) and Helios Media. Retrieved from http://www.communicationmonitor.asia

Matzler, K., Füller, J., Hutter, K., Hautz, J. \& Stieger, D. (2014). Open strategy: Towards a research agenda. Social Science Research Network. Retrieved from https://ssrn.com/abstract=2416937 or http://dx.doi.org/10.2139/ssrn.2416937

Michaelson, D. \& Stacks, D. (2011). Standardization in public relations measurement and evaluation. Public Relations Journal, 5(2), 1-22.

Mintzberg, H. (1978). Patterns in strategy formation. Management Science, 24(9), 231-255. https://doi.org/10.1287/mnsc.24.9.934

Mintzberg, H. (1979). The structure of organisations. Englewood Cliffs, NJ: Prentice Hall.

Mintzberg, H. \& Waters, J. (1985). Of strategies, deliberate and emergent. Strategic Management Journal, 6(2), 257-272. https://doi.org/10.1002/smj.4250060306

Moss, D. (2011) Strategy making and planning in the communications context. In D. Moss \& B. DE Santo (Eds.) Public relations: A managerial perspective. London: Sage

Murray, K. \& White, J. (2005). CEO's views on reputation management. Journal of Communication Management, 9(4), 348-358

Porter, M. E. (1989). Competitive Advantage. NY: Free Press

Porter, M.E. \& Kramer, M.R. (2011) Creating shared value. Harvard Business Review. January 2011

Pawson, R. \& Tilley, N. (1997). Realistic Evaluation. London, UK: Sage. 
Putnam, L. I. \& Nicotera, A. M. (2009). Building Theories of Organisation: The Constitutive Role of Communication, London: Routledge

Rigby, D.K., Sutherland, J. \& Takeuchi, H. (2016) Embracing Agile, Harvard Business Review, April, 2016

Rossi, P., Lipsey, M. \& Freeman, H. (2004). Evaluation: A systematic approach (7th ed.). Thousand Oaks, CA: Sage.

Rouleau, L. \& Balogun, J. (2011). Middle managers, strategic sense making and discursive competence. Journal of Management Studies, 48(5), 953-83

Scharmer, C. O. \& Kaeufer, K. (2010). In front of the blank canvas: sensing emerging future. Journal of Business Strategy, 31(4), 21 - 29

Schendel, D. \& Hofer, C. (1979) Introduction. In D. Schendel \& C. Hofer (Eds.), Strategic management (pp. 1-22). Boston, MA: Little, Brown.

Schreyoegg, G. \& Steinmann, H. (1987). Strategic control: A new perspective. Academy of Management Review, 12(1), 91-103. http://dx.doi.org/10.2307/257996

Starck, K. \& Kruckeberg, D. (2001). Public Relations and Community: A Reconstructed Theory Revisited. In RL Heath (Ed), Handbook of Public Relations, Thousand Oaks, Cal: Sage

Steyn, B. (2004). From Strategy to Corporate Strategy: A conceptualisation. Journal of Communication Management, 8(4), 168-183

Steyn, B. (2007). Contribution of Public Relations to Organizational Strategy Formulation. In E. Toth, (Ed.). The Future of Excellence in Public Relations and Communication Management. Mahwah, NJ: Lawrence Erlbaum Associates.

Steyn, B. (2004). From Strategy to Corporate Strategy: A conceptualisation. Journal of Communication Management, 8(4), 168-183

Suchman, E. (1967). Evaluative research: Principles and practice in public service and social action programs. New York, NY: Russell Sage Foundation.

Sutherland, J. (2014). Scrum: The Art of Doing Twice the Work in Half the Time, Crown Business

Taylor-Power, E., \& Henert, E. (2008). Developing a logic model: Teaching and training guide. Madison, WI: University of Wisconsin-Extension Program. Retrieved from https://fyi.uwex.edu/programdevelopment/files/2016/03/Imguidecomplete.pdf

Tencati, A. \& Zsolnai, L. (2009). The Collaborative Enterprise. Journal of Business Ethics. 85(3), $367-376$.

Torp, S. (2015). The strategic turn in communication science: On the history and role of strategy in science from ancient Greece until the present day. In D. Holtzhausen \& A. Zerfass (Eds.), The Routledge handbook of strategic communication (pp. 34-52). New York, NY: Routledge.

van Ruler, B. (2015). Agile public relations planning: The reflective communication scrum. Public Relations Review, 41(2), 187 -192

Watson, T., \& Noble, P. (2014). Evaluating public relations: A best practice guide to public relations planning, research and evaluation ( $3^{\text {rd }}$ ed.). London, UK: Kogan Page.

Weiss, C. (1972). Evaluative research: Methods of assessing program effectiveness. Englewood Cliffs, NJ: Prentice Hall. 
Wholey, J. (1970). Federal evaluation policy. Washington, DC: Urban Institute Press.

Wholey, J. (1979). Evaluation: Promise and performance. Washington, DC: Urban Institute Press.

Wholey, J. (1983). Evaluation and effective public management. Boston, MA: Little Brown \& Co.

Wholey, J. (1987). Evaluability assessment: Developing program theory. New Directions for Program Evaluation, 33, 77-92. https://doi.org/10.1002/ev.1447

de Wit R. (2017). Strategy (6 ${ }^{\text {th }}$ Edition), Andover: CENGAGE Learning EMEA

Wright, D., Gaunt, R., Leggetter, B., Daniels, M. \& Zerfass, A. (2009). Global survey of communications measurement 2009 - final report. London, UK: Association for Measurement and Evaluation of Communication. Retrieved from http://amecorg.com/wpcontent/uploads/2011/08/Global-Survey-Communications_Measurement-20091.pdf

Wright, D., \& Hinson, M. (2012). Examining how social and emerging media have been used in public relations between 2006 and 2012: A longitudinal analysis. Public Relations Journal, $6(4), 1-40$.

Zerfass, A. (2008). Corporate Communication Revisited: Integrating Business Strategy and Strategic Communication. In A. Zerfass, B van Ruler \& K. Sriramesh (Eds.) Public Relations Research. European and International Perspectives and Innovations. VS Verlag Fur Sozialwissenschaften, Wiesbaden

Zerfass, A., Verčič, D., Verhoeven, P., Moreno, A., \& Tench, R. (2015). European communication monitor 2015. Brussels, Belgium: European Association for Communication Directors (EACD) and European Public Relations Education and Research Association (EUPRERA) in association with Helios Media, Berlin. Retrieved from http://www.zerfass.de/ECMWEBSITE/media/ECM2015-Results-ChartVersion.pdf 